\title{
Dietary effect of silage type and combination with camelina seed on milk fatty acid profile and antioxidant capacity of sheep milk
}

\author{
D. Mierlita ${ }^{\#}$ \& S. Vicas \\ University of Oradea, Department of Animal Science, Oradea City, Romania
}

(Received 15 July 2014; Accepted 14 December 2014; First published online 7 February 2015)

\begin{abstract}
Copyright resides with the authors in terms of the Creative Commons Attribution 2.5 South African Licence.
See: http://creativecommons.org/licenses/by/2.5/za

Condition of use: The user may copy, distribute, transmit and adapt the work, but must recognise the authors and the South African Journal of Animal Science.
\end{abstract}

\begin{abstract}
The present study sought to quantify the differences between maize-based (MS) and grass-silagebased (GS) diets in terms of their effect on the milk yield, milk fatty acid composition and antioxidant capacity in dairy ewes, and to test the hypothesis that it is possible to improve yield, fatty acid (FA) composition and antioxidant capacity by supplementing diet with camelina seed (Cs). Experimental diets consisted of a $2 \times 2$ factorial arrangement of type of silage (GS vs. MS) and camelina seed (-Cs vs. $+C s)$. Feeding the MS diets increased net energy for lactation $\left(\mathrm{NE}_{\mathrm{L}}\right)$ intake, raw milk yield and fat, protein and lactose yields. Feeding $+C s$ increased energy corrected milk (ECM), milk fat content and fat yield. Maize silage consumption is associated with an increased proportion of hypercholesterolemic fatty acids (HFA) and a higher value of the atherogenicity index. However, an MS diet led to an increased share of t11-C18:1 and c9,t11-conjugated linoleic acid (CLA) in milk. Milk FA profile in ewes fed GS diet was of higher quality for human beings owing to higher concentrations of $\alpha$-linolenic acid and a lower content of HFA. Supplementing with camelina seed resulted in a higher concentration of t11-C18:1, c9,t11-CLA and C18:3n-3 in milk fat. The trolox equivalent antioxidant capacity (TEAC) value of milk was higher in milk from MS-fed ewes compared with that of their counterparts fed GS. Dietary supplementation with camelina seed increased the oxidative stability of milk samples. These results suggest that grass-silage-based diet supplemented with camelina seed results in milk of better quality for human consumption.
\end{abstract}

Keywords: Milk quality, oilseed, PUFA profile, oxidative stability of milk, TEAC assay

${ }^{\#}$ Corresponding author: dadi.mierlita@yahoo.com

\section{Introduction}

Sheep milk fat is rich in saturated fatty acids (SFA), mainly C12:0, C14:0 and C16:0 (hypercholesterolaemic fatty acids (HFA)), which have a negative effect on human health (Williams, 2000). Oleic acid (C18:1 cis-9), a-linolenic acid (C18:3 n-3; ALA), eicosapentaenoic acid (EPA, C20:5 n-3), docosahexaenoic acid (DHA, C22:6 n-3) and conjugated linoleic acid (CLA, C18:2 cis-9 trans-11) have positive effects on human health. They reduce the risk of cardiovascular disease, are anti-carcinogenic, and have anti-sclerosis properties (Massaro et al., 1999; Lopez-Huertas, 2010). Therefore, maximizing ALA, EPA, DHA (poly-unsaturated fatty acid (PUFA) n-3: PUFA n-3) and CLA in milk and dairy products would benefit human health.

Major changes in milk fatty acid (FA) composition can be induced by manipulating nutrition, such as feeding pasture, conserved forages, starchy concentrates and diets supplemented with oilseeds (Ferlay et al., 2011). Supplementing ruminant diets with oil (sunflower, soya, linseed, canola) has a stronger negative effect on intake, fibre digestion, rumen metabolism and milk FA profile than seeds (Chilliard et al., 2003; Andrade et al., 2006). Using seeds as a source of fat is a more convenient practice than using oils, because of their limited ruminal hydrogenation of FA (Chilliard et al., 2001).

Camelina (Camelina sativa L.) is native to the Finland to Romania region, and east to the Ural Mountains. Because camelina seed contains a high concentration of long-chain unsaturated FAs (total PUFA: 65.8\%; linoleic acid: 22.1\%; $\alpha$-linolenic acid: 43.7\% (Mierlita et al., 2011)), its FA spectrum is similar to that of fish oil (AbuGhazaleh et al., 2007; Hunter \& Roth, 2010) and linseed (Hurtaud \& Peyraud, 2007; Cieslak et al., 2010). Seeds rich in linoleic acid (e.g. soya and sunflower) can influence the C18:1 trans and CLA profile in milk, while seeds rich in a-linolenic acid (e.g. linseed, camelina seed) affect primarily the C18:3 concentration in milk (Chilliard et al., 2003; Gomez-Cortes et al., 2009; Mierlita et al., 2011). In addition, 
camelina seed contains gamma tocopherol (vitamin E), which acts as an antioxidant, and increases the stability of oil compared with other oilseeds (Budin et al., 1995).

An increased proportion of unsaturated fat in milk may augment its oxidative susceptibility. To maintain a high quality, the concentration of antioxidants should therefore be elevated (Slots et al., 2009). In milk, the concentration of $\alpha$-tocopherol and carotenoids as antioxidants is believed to be important for oxidative stability. High concentrations of $\alpha$-tocopherol and $\beta$-carotene in milk can be obtained from a high proportion of pasture or grass clover silage in the diet of ruminants (Havemose et al., 2004; Renobales et al., 2012), because these types of forage are high in antioxidants (Lynch et al., 2001). Maize silage (MS) and grass silage (GS) have great potential in the nutrition of ewes, especially over four to five months of winter feeding when ewes are kept indoors. Milk production is higher when using maize silage than grass silage owing to higher starch content and digestibility (Nielsen et al., 2006), which makes this system more competitive in terms of production and economic outcome. However, comparisons between maize silage and grass silage as sheep feed options have not been made in terms of their effects on the FA profile of the milk, with particular reference to HFA, PUFA n-3 and CLA, which affect human health. In addition, studies on the antioxidant activity of sheep milk are limited (Renobales et al., 2012). Most of the published studies refer to cows' milk (Chilliard \& Ferlay, 2004), probably because of its large volume and economic importance, although from a nutritional point of view, ovine milk is better than bovine milk (Renobales et al., 2012; Claeys et al., 2014). The effects of type of silage and supplementation of the ewes' diet with camelina seed on milk FA profile and oxidative stability are not well documented.

Hence, the aim of this study was to find out whether the composition of milk could be manipulated to become closer to recent dietary recommendations for human beings, and thus have a higher concentration of PUFA and a high oxidative stability by feeding ewes maize- and grass-silage-based diets and supplementing with camelina seed (Camelina sativa L).

\section{Materials and Methods}

The study was conducted at the University of Oradea (Romania) over a 10-week period. The first three weeks were used as a covariate period (week 1) and for adaptation to dietary treatments (weeks 2 and 3 ). After weaning the lambs (72 \pm 14 days in milk), 40 multiparous Turcana ewes (liveweight $44.9 \pm 2.7 \mathrm{~kg}$; parity $2.4 \pm 0.16$ ) were divided into four homogeneous groups (10 ewes/group). At the onset of the trial, ewes averaged $744.7 \pm 148.5 \mathrm{~g} /$ day milk yield containing $66.8 \pm 11.2 \mathrm{~g}$ milk fat $/ \mathrm{L}$. The four groups were assigned randomly to one of four dietary groups arranged in a $2 \times 2$ factorial design. The main treatment factor was type of silage (grass or maize) and the second was type of supplement (with or without fat). The source of fat was camelina seed (Camelina sativa L.), which contains $37.6 \%$ crude fat, and has a high concentration of PUFA (in particular linoleic acid: $22.1 \%$ and $\alpha$-linolenic acid: 43.7\%) (Mierlita et al., 2011). The diets of the four ewe groups were as follows:

- GS/-Cs: grass-silage-based diet, with no supplement

- GS/+Cs: grass-silage-based diet, complemented with $70 \mathrm{~g} / \mathrm{kg}$ (DM) diet of camelina seed

- MS/-Cs: maize-silage-based diet, with no supplements

- MS/+Cs: maize-silage-based diet complemented with $70 \mathrm{~g} / \mathrm{kg} \mathrm{DM}$ diet of camelina seed

Grass silage was prepared from the vegetation on a meadow, with a plant species composition of ca. 57\% Dactylis glomerata, 10\% Phleum pratense, 8\% Poa pratensis, 7\% Festuca rubra, 13\% legumes (mainly Trifolium repens) and $5 \%$ other grasses. Botanical composition was determined at mowing by calculating the weight of 30 forage samples taken randomly by quadratic frame $\left(0.25 \times 0.25 \mathrm{~m}^{2}\right)$ by manual separation of plant species. The meadow was harvested at the early flowering stage. Forage DM content at harvest was $284 \mathrm{~g} / \mathrm{kg}$ fresh sample. The crop was mown and allowed to wilt for 24 hours before harvesting with a round baler. Bales were wrapped in four layers of plastic.

The maize crop (Zea mays L.) was sown with a row space of $75 \mathrm{~cm}$ and 70000 plants/ha. Whole crop maize was harvested to a nominal stubble height of $20 \mathrm{~cm}$ above ground (pre-harvest DM of $305 \mathrm{~g} / \mathrm{kg}$ fresh weight, while the cob DM to total DM ratio was $6: 1$ ).

Diets consisted of a total mixed ration (TMR) (forage : concentrate ratio $70: 30$ on a DM basis) (Table 1 ), formulated to be isonitrogenous. The diets were freshly prepared daily, and offered ad libitum as two meals at 08:30 and 16:30. Refusals were removed and weighed prior to the morning feeding.

During weeks 2 and 3, the ewes were gradually switched to one of the four experimental diets: week 2 was for adaptation to the type of silage; and week 3 for adaptation to lipid supplementation.

The ewes were milked twice daily (07:30, 20:30), and milk yield was recorded. Milk fat, lactose and protein levels were recorded on two consecutive days each week. Samples from two consecutive milking sessions were taken on week 6 and week 10 to determine the FA profile of milk fat.

Samples of the diets were collected in weeks 3, 5, 7 and 10 of the experiment period $(n=4)$, stored at $-20^{\circ} \mathrm{C}$, then used for chemical composition analysis. The diets were analysed for DM (ISO, 1999a), neutral 
detergent fibre (NDF) and acid detergent fibre (ADF) (Van Soest et al., 1991) on a Fibersac analyser (Ankom Technology, Fairport, NY), nitrogen (N) (Kjeldahl technique) and ether extract (AOAC, 1996). Starch of the oven-dried materials was determined by a colorimetric method (Dubois et al., 1956).

Samples $(n=2)$ of diets were collected on weeks 6 and 10 to determine the FA profile. These samples were stored immediately at $-20^{\circ} \mathrm{C}$, and later lyophilized and kept until analysis.

Milk samples were preserved with two tablets of Bronopol ${ }^{\circledR}$ (BroadSpectrum Micro-tabs II, D\&F Control Systems Inc., USA). The samples were refrigerated at $4{ }^{\circ} \mathrm{C}$ before being analysed for fat and protein content by infrared analysis (Milk Analyser System 4000, Foss Electric, Hillerod, Denmark). Monohydrate lactose content was measured on these samples using an enzymatic method (FIL, 1991). Samples of milk collected on weeks 6 and 10 for FA analysis were frozen at $-20^{\circ} \mathrm{C}$ without preservatives.

To determine the concentration of FAs in the diets, fatty acid methyl esters (FAME) were prepared by the one-step extraction-methylation method of Sukhija \& Palmquist (1988). In order to determine the composition of FAs in milk, the fat was extracted according to the international standard, ISO 14156 / IDF 172:2001. FAME were prepared according to the method proposed by Christie (1982) and Chouinard et al. (1999) and were determined by gas chromatography using a Varian GC 3600 equipped with FID and a fused silica capillary column (SP 2560 Supelco), $100 \mathrm{~m} \times 0.25 \mathrm{~mm}$ i.d., film thickness $0.20 \mu \mathrm{m}$. Helium was used as the carrier gas at a flow rate of $1 \mathrm{~mL} / \mathrm{min}$. The split ratio was $1: 100$. The oven temperature was programmed at $90^{\circ} \mathrm{C}$ and held for $1.50 \mathrm{~min}$, then increased to $210^{\circ} \mathrm{C}$ at a rate of $9{ }^{\circ} \mathrm{C} / \mathrm{min}$, held at this temperature for $25 \mathrm{~min}$, then increased to $230^{\circ} \mathrm{C}$ at $15^{\circ} \mathrm{C} / \mathrm{min}$, and held for $7 \mathrm{~min}$. The temperatures of the injector and the detector were set at $270^{\circ} \mathrm{C}$. The FA identification was based on external standards, and calculation of the distribution (in weight percentage) was based on the area of each FA ester corrected for the response factors for the individual FAs. Internal standards were used to determine the percentage of recovery. The CLA isomer reported is cis-9, trans-11 C18:2. The percentage of each FA was calculated by dividing the area under the FA peak by the sum of the areas under the total reported FA peaks.

Antioxidant activity of milk and experimental diets samples was estimated by the TEAC method, according to Renobales et al. (2012), which measures the ability of compounds to scavenge the 2,2'-azinobis(3-ethylbenzthiazoline-6-sulphonic acid) (ABTS) radical cation in relation to trolox. ABTS was dissolved in distilled water to a $7 \mathrm{mM}$ concentration. $\mathrm{ABTS}^{+}$was produced by reacting ABTS stock solution with $2.45 \mathrm{mM}$ potassium persulphate and allowing the mixture to stand in the dark at room temperature for 12 - 16 hours before use. ABTS stock solution was diluted with saline phosphate buffer $(0.15 \mathrm{M}, 5 \mathrm{mM}$ phosphate, $\mathrm{pH}$ 6.7) in order to obtain an absorbance of $0.70 \pm 0.02$ at $730 \mathrm{~nm}$. After adding $0.5 \mathrm{~mL}$ of various concentrations of trolox $(0-20 \mu \mathrm{M})$ or milk samples to $2.0 \mathrm{~mL}$ of diluted $\mathrm{ABTS}^{+}$(working solution), the absorbance was read at $730 \mathrm{~nm}$ after 10 minutes at $25^{\circ} \mathrm{C}$. A blank sample was used to correct the residual turbidity. In the milk samples the results were expressed as $\mu \mathrm{mol}$ trolox equivalent normalized according to the protein content of each milk sample ( $\mu \mathrm{mol}$ trolox equivalent/g protein), and for experimental diets as $\mu \mathrm{mol}$ trolox equivalent/100 $\mathrm{g}$. The $\mathrm{pH}$ of milk samples was adjusted to 6.7 , and diluted 10 times before measurements.

The atherogenicity index (Al) was calculated according to Chilliard et al. (2003) as follows:

(C12:0 + 4 x C14:0 + C16:0)/(MUFAs + PUFAs).

The data for the chemical composition of experimental diets, milk yield, milk compositions, FA in milk fat and TEAC were analysed as a $2 \times 2$ factorial randomized block design using the PROC MIXED models of SAS Institute (SAS, 2001). Fixed effects were the type of silage (GS and MS), camelina seed supplementation (Cs), interactions between them (silage $\times$ Cs), time and an appropriate covariate. Random effects of ewe were used as the error term. Variance-covariance structure was first autoregressive (AR(1)). For FA proportion in milk fat, analysis was performed without covariate. Overall differences between treatment means and interaction for silage type and camelina seeds were considered significant at $P<0.05$. Trends for significance were declared at $P=0.05$ to 0.10 .

\section{Results and Discussion}

The chemical composition of the experimental diets is presented in Table 1 and FA levels and antioxidant capacity of diets in Table 2. As expected, the MS diets had the highest starch content, while diets $+C s$ had the highest content of crude fat $(P<0.001)$. The two feeding systems offered similar protein and net energy for lactation $\left(\mathrm{NE}_{\mathrm{L}}-\mathrm{MJ} / \mathrm{kg}\right)$ contents.

Diets based on grass silage had a higher PUFA concentration, especially PUFA n-3, compared with the maize-silage diets, which had a higher PUFA n-6 content. Supplementing the ewes' diet with camelina seeds doubled the FA level in the diet and improved their profile through the increase in PUFA $n-3$ concentrations and the decrease in the proportions of saturated FAs (Table 2). Although the plant belongs to the Crucifera family, camelina seeds have a high content of PUFA, especially $\alpha$-linolenic acid (C18:3 n-3), which is comparable with the concentrations in linseed (Hurtaud \& Peyraud, 2007; Cieslak et al., 2010). The antioxidant capacity of the diets registered higher values with the MS diets because wilting of the grassy 
meadow for 24 hours probably led to the destruction of antioxidizing factors such as carotenoids and tocopherols, since $80 \%$ of the carotenoid content of grass is known to be destroyed in the process of making hay (Chauveau-Duriot et al., 2005). The camelina seeds induced a higher TEAC value (trolox equivalent antioxidant capacity) in + Cs diets, possibly owing to the high tocopherol content, which have high antioxidant activity (Budin et al., 1995).

Feeding the MS diets increased $\mathrm{NE}_{\mathrm{L}}$ intake, raw milk yield and fat, protein and lactose yields (Table 3 ). Feeding $+C s$ increased energy-corrected milk $(E C M)$, milk fat content and fat yield $(P<0.01)$. Milk lactose level was not affected by dietary factors. The raw milk yield, milk fat and milk protein levels were relatively constant (effect of wk: $P>0.10$ ) during the trial (data not shown). An increase in milk protein concentration may be attributed to microbial protein synthesis being energetically more efficient on MS than on GS-based diets (Givens \& Rulquin, 2004).

The type of silage in the diet had no effect on milk fat content. Typically, increases in starch intake, such as from the MS diets, are associated with a reduction in milk fat (Lock \& Shingfield, 2004; Nielsen et al., 2006). A lack of effect on milk fat concentrations in this experiment may reflect an equal intake of NDF in the MS and GS diets (Kliem et al., 2008).

Table 1 Ingredients and chemical composition of experimental diets

\begin{tabular}{|c|c|c|c|c|c|c|c|c|}
\hline \multirow[b]{2}{*}{ Fat supplementation } & \multicolumn{2}{|c|}{ Grass silage } & \multicolumn{2}{|c|}{ Maize silage } & \multirow{2}{*}{ SEM } & \multicolumn{3}{|c|}{$P$ values of effects ${ }^{1}$} \\
\hline & - Cs & $+\mathrm{Cs}$ & - Cs & + Cs & & $\mathbf{S}$ & Cs & $\mathrm{S} \times \mathrm{Cs}$ \\
\hline \multicolumn{9}{|c|}{ Ingredients (g/100 g of dry matter) } \\
\hline Maize silage & - & - & 45.0 & 45.0 & & & & \\
\hline Grass silage & 45.0 & 45.0 & - & - & & & & \\
\hline Lucerne hay & 25.0 & 25.0 & 25.0 & 25.0 & & & & \\
\hline $\begin{array}{l}\text { Maize } \\
\text { Soybean meal }\end{array}$ & $\begin{array}{l}21.3 \\
7.0\end{array}$ & $\begin{array}{c}17.8 \\
3.5\end{array}$ & $\begin{array}{l}18.3 \\
10.0\end{array}$ & $\begin{array}{c}15.3 \\
6.0\end{array}$ & & & & \\
\hline Camelina seed & - & 7.0 & - & 7.0 & & & & \\
\hline Calcite $^{2}$ & 0.5 & 0.5 & 0.5 & 0.5 & & & & \\
\hline Sodium bicarbonate & 0.7 & 0.7 & 0.7 & 0.7 & & & & \\
\hline Trace-mineralized salt & 0.3 & 0.3 & 0.3 & 0.3 & & & & \\
\hline Vitamin mix & 0.2 & 0.2 & 0.2 & 0.2 & & & & \\
\hline \multicolumn{9}{|c|}{ Chemical composition of experimental diets } \\
\hline Dry matter (DM) & 63.7 & 63.8 & 64.2 & 64.3 & 17.1 & NS & NS & NS \\
\hline $\mathrm{CP}(\%$ of $\mathrm{DM})$ & 14.88 & 14.85 & 14.59 & 14.57 & 0.88 & NS & NS & NS \\
\hline Crude fat $(\%$ of DM) & 3.39 & 6.27 & 3.09 & 6.01 & 0.84 & NS & 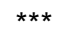 & NS \\
\hline Starch (g/kg DM) & 304.3 & 289.1 & 386.0 & 374.5 & 12.73 & $\star \star$ & NS & $\dagger$ \\
\hline NDF (\% of DM) & 37.0 & 37.3 & 29.9 & 30.2 & 1.67 & $\star \star$ & NS & NS \\
\hline ADF (\% of DM) & 23.6 & 23.9 & 18.6 & 18.9 & 0.83 & $\star *$ & NS & NS \\
\hline $\mathrm{PDIN}^{3}$ (g/kg DM) & 98.3 & 99.1 & 101.6 & 101.2 & 1.12 & NS & NS & NS \\
\hline $\mathrm{PDIE}^{3}$ (g/kg DM) & 82.1 & 83.7 & 99.3 & 100.4 & 0.94 & * & NS & NS \\
\hline $\mathrm{NE}_{\mathrm{L}}^{4}(\mathrm{MJ} / \mathrm{kg} \mathrm{DM})$ & 6.26 & 6.31 & 6.33 & 6.38 & 0.51 & NS & NS & NS \\
\hline
\end{tabular}

Cs: camelina seed (with no supplements: -Cs; completed with: +Cs);

SEM: standard error of mean.

$\mathrm{CP}$ : crude protein; NDF: neutral detergent fibre; ADF = acid detergent fibre.

${ }^{1} \mathrm{~S}$ : effect of type of silage; Cs: effect of camelina seed; $\mathrm{S} \times \mathrm{Cs}$ : interaction between type of silage and camelina seed.

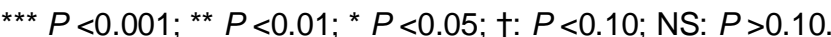

${ }^{2}$ Contained $38.5 \%$ Ca.

${ }^{3}$ Calculated values (INRA, 1989). PDIN and PDIE: digestible CP in the intestine from microbial protein synthesis when availability of fermentable $\mathrm{N}$ in the rumen is limiting, and from microbial protein synthesis when availability of energy in the rumen is limiting, respectively.

${ }^{4} \mathrm{NE}_{\mathrm{L}}$ : net energy for lactation. The value of $\mathrm{NE}_{\mathrm{L}}$ was estimated according to INRA (1989). 
Table 2 Fatty acid (FA) profile and antioxidant capacity for experimental diets ${ }^{1}$

\begin{tabular}{|c|c|c|c|c|}
\hline \multirow[b]{3}{*}{ Fat supplementation } & \multicolumn{4}{|c|}{ Treatment $^{2}$} \\
\hline & \multicolumn{2}{|c|}{ Grass silage } & \multicolumn{2}{|c|}{ Maize silage } \\
\hline & - Cs & + Cs & - Cs & $+\mathrm{Cs}$ \\
\hline Fatty acids (g/kg DM) & 27.2 & 56.1 & 27.0 & 54.8 \\
\hline \multicolumn{5}{|l|}{ Fatty acid composition (\% of FAME) } \\
\hline C12:0 & 0.19 & 0.21 & 0.36 & 0.48 \\
\hline C14:0 & 0.92 & 0.91 & 0.47 & 0.47 \\
\hline C16:0 & 19.37 & 18.51 & 16.43 & 15.58 \\
\hline C16:1 n-9 & 0.60 & 0.56 & 0.65 & 0.61 \\
\hline C18:0 & 4.12 & 4.09 & 3.87 & 3.85 \\
\hline C18:1 n-9c & 11.85 & 11.07 & 22.05 & 21.31 \\
\hline C18:1 n-7c & 0.80 & 0.78 & 0.95 & 0.96 \\
\hline C18:2 n-6c & 37.3 & 35.4 & 43.7 & 41.6 \\
\hline C18:3 n-6 & 0.37 & 0.46 & 0.19 & 0.28 \\
\hline C18: n-3 & 21.80 & 24.34 & 8.94 & 11.48 \\
\hline C20:1 & 0.84 & 1.65 & 0.72 & 1.53 \\
\hline C22:1 & ND & 0.22 & ND & 0.23 \\
\hline Others & 1,84 & 1.79 & 1.71 & 1.59 \\
\hline $\mathrm{SFA}^{3}$ & 24.60 & 23.72 & 21.13 & 20.38 \\
\hline MUFA $^{4}$ & 14.09 & 14.28 & 24.37 & 24.63 \\
\hline PUFA $^{5}$ & 59.6 & 60.2 & 52.8 & 53.4 \\
\hline PUFA n-6 & 37.7 & 35.9 & 43.9 & 41.9 \\
\hline PUFA n-3 & 21.80 & 24.34 & 8.94 & 11.48 \\
\hline TEAC ( $\mu \mathrm{mol}$ TE/100 g diet) & 95.4 & 99.2 & 109.5 & 113.4 \\
\hline
\end{tabular}

The inclusion of fats rich in PUFA in the diet of dairy cows causes a decrease in milk fat yield, known as the milk fat depression (MFD) syndrome. The opposite appears to occur with dairy ewes supplemented with camelina seed $(+\mathrm{Cs})$, which increased their milk fat yield. These discrepancies between species could be because of the low amounts of trans FA (trans-10 C18:1, trans-10, cis-12 C18:2, and trans-9, cis-11 C18:2) in ewe milk fat that were proposed in cow milk fat synthesis inhibitors (Gomez-Cortes et al., 2008).

Previous studies reported that grass and maize silage alter the FA composition of cows' milk (Nielsen et al., 2006; Ferlay et al., 2011). The current study was designed to examine changes in milk FA composition when diets based on grass or maize silage were supplemented with a constant proportion of concentrate with camelina seed. It was conducted in order to develop practical nutritional strategies to reduce milk fat SFA and HFA content, increase PUFA, and improve the oxidative stability of sheep milk.

The effects of the treatments on the FA profile of milk fat and antioxidant capacity are presented in Table 4. There were significant effects of type of silage on C12:0, C14:0, C14:1, C15:0, C16:0, C17:0, C17:1, C18:1, C18:1 trans-11 (TVA: trans-vaccenic acid), cis-9 trans-11 CLA (rumenic acid-RA), C18:3 n-3 (ALA: a-linolenic acid) and C20:5 n-3 (EPA: eicosapentaenoic acid) $(P<0.05)$ concentrations. The remaining milk FA levels were not affected significantly by type of silage.

Ewes in the MS group exhibited a higher level of milk fat of C12:0, C16:0, C17:0, C17:1, TVA and cis9 trans-11 CLA than the GS group $(P<0.01)$. By contrast, the C14:0, C15:0, C18:1 cis-9, C18:3 n-3 (ALA) 
and C20:5 n-3 (EPA) contents were higher in the milk fat of the GS group $(P<0.01)$. When dairy ewes were fed diets MS with high non-fibrous carbohydrates (NFC) that is, sugars, starch, and soluble fibre, the concentrations of TVA and c9,t11 CLA in milk increased, indicating that when the NFC in the diet is raised, the biohydrogenation of unsaturated FA in the rumen probably slows down, and a higher amount of unsaturated FA escapes the rumen, reaching the mammary gland. Maize silage may enhance the growth of specific bacteria in the rumen, stimulating the production of CLA and the reduction of TVA to stearic acid (C18:0) (Nudda et al., 2006). In this sense, the MS diet is richer in C18:2 n-6 (43.66 vs. 37.30) (Table 2), which can stimulate CLA production. Increases in the concentrations of C14:0, C15:0, cis-9 C18:1 (oleic acid) and cis-11 C18:1 in milk fat and a decrease in the concentration of C16:0 were recorded in cows fed on grass silage compared with those fed on maize silage (Vlaeminck et al., 2006). A more complete hydrogenation of PUFA into C18:0 in rumen probably helped the increase in oleic acid in milk fat, as this FA is endogenously synthesized in the mammary gland via $\Delta^{5}$-desaturase of C18:0 (Chilliard et al., 2003).

The GS ewes presented a significantly greater ratio of PUFA n-3 in the milk than the MS group ( $P$ $<0.01$ ), which is consistent with their higher proportion in grass silage than in maize silage (Table 2). Total PUFAs in milk were greater in the GS group than in the MS group owing to the greater amount of $\alpha$-linolenic acid (C18:3 n-3) and EPA (C20:5 n-3) in milk from GS ewes than in milk from MS ones. The EPA increase in the GS sheep milk was probably owing to de novo synthesis of the FA from C18: 3 n-3 in the mammary gland, since the GS diet has a much higher content of linolenic acid than the MS diet (21.80 vs. 8.94) (Table 2).

Table 3 Production parameters of dairy ewes fed grass silage (GS) or maize silage (MS) diets with (+Cs) or without (-Cs) camelina seed ${ }^{1}$

\begin{tabular}{|c|c|c|c|c|c|c|c|c|}
\hline \multirow[b]{2}{*}{ Fat supplementation } & \multicolumn{2}{|c|}{ Grass silage } & \multicolumn{2}{|c|}{ Maize silage } & \multirow{2}{*}{ SEM } & \multicolumn{3}{|c|}{$P$ values of effects ${ }^{2}$} \\
\hline & $-\mathrm{Cs}$ & $+\mathrm{Cs}$ & $-\mathrm{Cs}$ & $+\mathrm{Cs}$ & & $\mathbf{S}$ & Cs & $\mathrm{S} \times \mathrm{Cs}$ \\
\hline DMI (kg/day) & 2.848 & 2.795 & 3.081 & 3.032 & 0.074 & * & NS & NS \\
\hline Milk yield (g/day) & 704.6 & 775.8 & 786.5 & 810.1 & 26.4 & * & * & * \\
\hline $\mathrm{ECM}^{3}$ (kg/day) & 0.653 & 0.729 & 0.750 & 0.795 & 0.041 & $\star *$ & * & * \\
\hline Milk fat (g/L) & 66.9 & 68.3 & 67.9 & 72.7 & 1.23 & NS & $\star *$ & $\dagger$ \\
\hline Milk protein (g/L) & 53.4 & 54.0 & 58.0 & 56.6 & 0.62 & * & NS & NS \\
\hline Milk lactose (g/L) & 47.8 & 48.9 & 48.1 & 48.0 & 0.46 & NS & NS & NS \\
\hline Fat yield (g/day) & 47.2 & 53.0 & 53.4 & 58.9 & 1.72 & * & $* *$ & * \\
\hline Protein yield (g/day) & 37.6 & 41.9 & 45.6 & 45.8 & 0.59 & * & NS & $\dagger$ \\
\hline Lactose yield (g/day) & 33.6 & 38.0 & 37.9 & 38.9 & 0.84 & * & * & NS \\
\hline $\mathrm{NE}_{\mathrm{L}}$ intake (MJ/day) & 17.8 & 17.6 & 19.5 & 19.3 & 0.22 & * & NS & NS \\
\hline
\end{tabular}

A significantly higher share of hypercholesterolaemic FAs (HFA: C12:0 + C14:0 + C16:0) was found in the milk of sheep in the MS group compared with GS group of sheep $(P<0.05)$, probably owing to the high consumption of starch in the maize silage, which is associated with increased de novo synthesis of saturated FA, resulting in increased milk level (Kalac \& Samkova, 2010). The high concentration of starch in the diet increases FA biohydrogenation in the rumen and reduces the flow of linoleic acid and linolenic acid to the duodenum (Chilliard et al., 2003).

Milk fat from MS diet ewes (supplemented or not with Cs) had more than 30\% c9,t11-CLA isomer than milk fat from the GS diet ewes (Table 4). This positive effect of maize-silage intake on milk fat c9,t11-CLA content has previously been found in dairy cows (Nielsen et al., 2006; Samkova et al., 2009). While Samkova et al. (2009) found a significant difference in CLA level $(0.48 \%$ and $0.92 \%$ after feeding cows 
maize and grass silage, respectively), Shingfield et al. (2005) did not find any significant effect of silage type on total CLA and c9,t11-CLA proportions.

Dietary camelina seed modified milk FA composition towards a lower level of SFA and a higher level of PUFA and MUFA, confirming that an adequate dietary strategy can improve sheep milk quality. Including camelina seed in the diet resulted in a significant increases in rumenic acid (c9,t11-CLA) and vaccenic acid (t11-C18:1), as well as a-linolenic acid (C18:3) in milk fat $(P<0.01)$. Interactions among silage type and camelina seed resulted in a significant increase in rumenic acid, $\alpha$-linolenic and oleic acids $(P<0.05)$. Group $\mathrm{MS} /+\mathrm{Cs}$ milk had the highest concentration of the isomer c9,t11-CLA and TVA.

The amount of the CLA isomer cis-9, trans-11 in the milk of group +Cs was higher by $37.7 \%$ than the level present in the milk of group -Cs, which is higher than the increase obtained with sunflower oil (GómezCortés et al., 2011), but not as high as the 4.4 -fold increase obtained with a mixture of $2 \%$ sunflower and $1 \%$ fish oil (Toral et al., 2010). The concentration of TVA in the milk of group +Cs was 1.4-fold higher than that of group -Cs, lower than the 4.7-fold increase reported by Gómez-Cortés et al. (2011) for the diets containing $5.1 \%$ sunflower oil and the 5.1-fold value obtained with the mixture of sunflower and fish oils (Toral et al., 2010). The increase in TVA concentration in the +Cs ewes' milk is important because the vaccenic acid in human tissues can be converted to the c9,t11-CLA isomer (Turpeinen et al., 2002).

Butyric acid levels (BA - C4:0) in milk fat during the experiment were not affected by experimental diets. In contrast to our results, Puppel et al. (2013) observed a significant increase in BA levels in milk from cows receiving diets supplemented with fish oil.

Unlike the results obtained in the present study, in dairy cows camelina seeds did not cause an increase in C18:3 concentration in milk fat, despite an intake of $630 \mathrm{~g}$ camelina seed/day (Hurtaud \& Peyraud, 2007). This is probably because of substantial hydrogenation of C18:3 in the rumen and perhaps incomplete digestibility of oils in seed form with the Cs diet. In the present study, the digestibility of camelina seeds might not have been sufficiently efficient to make oil rapidly available to ruminal microorganisms, and/or the quantity of added fat was not high enough to alter FA biohydrogenation.

The reduction of medium-chain FA (C12-C14) concentration by camelina seed supplementation observed in this study is consistent with that reported by Gomez-Cortes et al. (2009) for diet with extruded linseed supplementation.

Ewes fed +Cs combined with grass silage diet had the lowest proportion of C12:0, C16:0 and C17:0 (S x Cs: $P<0.10$ to 0.05 ) in milk fat; conversely they had the highest proportion of c9-C18:1, C18:3 n-3, C20:5 n-3 and C22:6 n-3 in milk fat ( $\mathrm{S} \times \mathrm{Cs}: P<0.05$ to 0.001). Ewes fed + Cs combined with the maize silage diet had the lowest proportion of C14:0, C15:0, C20:0 (S x Cs: $P<0.10$ to 0.05$)$ in milk fat; conversely they had the highest proportion of t11-C18:1 and c9,t11-CLA (S x Cs: $P<0.10$ to 0.05 ).

The decrease in $\mathrm{C} 12: 0, \mathrm{C} 14: 0$ and $\mathrm{C} 16: 0$ concentrations resulted in the reduction of the milk fat atherogenic index (Al) of GS diet ewes and those whose diet was supplemented with camelina seed (+Cs), compared with MS diet and - Cs diet respectively $(P<0.05)$ (Table 4).

Ratios of product/(substrate + product) were estimated to assess the extent of desaturation of specific FAs during milk fat synthesis (Mele et al., 2006). The higher values of these ratios indicate that the desaturation of FA substrates is more intense in ewes that were not fed camelina seeds. Our results were consistent with those reported by Mierlita et al. (2011) with ewes grazing on native pasture and completing diet with grain and camelina seed, and by Bernard et al. (2005) for dairy goats fed a hay-based diet supplemented or unsupplemented with linseed or sunflower oil. The data indicate that the FA composition of milk can be improved from a human health perspective by including grass silage in the diet and supplementing it with camelina seed.

Increase in unsaturated nutritionally beneficial FAs can contribute to increased oxidation susceptibility of milk fat and adverse changes in the nutritional and dietetic properties of milk. The researchers found a variation in antioxidant activity between the milk from GS group sheep and the MS group (Table 4). The TEAC (trolox equivalent antioxidant capacity) value was significantly higher in the milk from the MS sheep group $(P<0.01)$ compared with the GS group ( 0.133 vs. $0.105 \mu \mathrm{mol}$ trolox equivalent/g protein) owing to higher concentrations of cis-9, trans-11 CLA, which have been shown to have a high antioxidant activity (Park et al., 2007). The trend of decreasing oxidative stability of milk in a grass-silage-based diet may be owing to a higher degree of lipid oxidation caused by higher levels of C18:3 n-3. Similar results on the antioxidant activity of milk were obtained by Havemose et al. (2006) in cows fed grass- or maize-silagebased diets.

Supplementing ewe diets with camelina seed led to an increase in TEAC values in milk samples by $44.2 \%-84.5 \%(P<0.001)$, the increase being higher in the grass-silage-based diet. This rise in the antioxidant capacity of milk was because of augmented levels of natural antioxidants (tocopherols and 
Table 4 Fatty acid profile (\% of FAME) and antioxidant capacity of milk fat from dairy ewes fed grass silage (GS) or maize silage (MS) diets combined with (+Cs) or without (-Cs) camelina seed ${ }^{1}$

\begin{tabular}{|c|c|c|c|c|c|c|c|c|}
\hline \multirow{2}{*}{ Fat acids } & \multicolumn{2}{|c|}{ Grass silage } & \multicolumn{2}{|c|}{ Maize silage } & \multirow{2}{*}{ SEM } & \multicolumn{3}{|c|}{$P$ values of effects ${ }^{2}$} \\
\hline & $-\mathrm{Cs}$ & $+\mathrm{Cs}$ & $-\mathrm{Cs}$ & $+\mathrm{Cs}$ & & 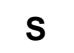 & Cs & $\mathrm{S} \times \mathrm{Cs}$ \\
\hline $\mathrm{C} 4: 0$ & 2.85 & 2.33 & 2.86 & 2.53 & 0.167 & NS & NS & NS \\
\hline $\mathrm{C} 6: 0$ & 2.37 & 2.20 & 2.49 & 2.59 & 0.148 & NS & NS & NS \\
\hline C8:0 & 2.48 & 2.19 & 2.32 & 2.05 & 0.161 & NS & NS & NS \\
\hline C10:0 & 7.57 & 7.27 & 7.87 & 7.50 & 0.245 & NS & NS & NS \\
\hline $\mathrm{C} 12: 0$ & 4.19 & 2.30 & 6.94 & 4.41 & 0.092 & $\star \star$ & $\star *$ & $\dagger$ \\
\hline C14:0 & 9.25 & 8.22 & 8.28 & 7.54 & 0.627 & ** & * & * \\
\hline C14:1 & 0.12 & 0.11 & 0.29 & 0.42 & 0.016 & * & $\star \star$ & $\star \star$ \\
\hline C15:0 & 0.89 & 0.81 & 0.46 & 0.20 & 0.065 & $\star \star \star *$ & ** & ** \\
\hline $\mathrm{C} 16: 0$ & 20.66 & 18.78 & 24.25 & 23.94 & 1.081 & $\star *$ & * & $\dagger$ \\
\hline C16:1 & 0.65 & 0.58 & 0.69 & 0.68 & 0.056 & NS & NS & NS \\
\hline C17:0 & 0.56 & 0.53 & 1.41 & 0.84 & 0.195 & $* \star \star$ & $\star \star *$ & * \\
\hline C17:1 & 0.31 & 0.24 & 0.73 & 0.58 & 0.027 & 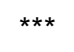 & $\dagger$ & NS \\
\hline C18:0 & 13.30 & 12.94 & 13.01 & 12.93 & 0.562 & NS & NS & NS \\
\hline C18:1 n9t & 0.52 & 0.75 & 0.28 & 0.50 & 0.078 & $* *$ & * & * \\
\hline C18:1 trans-11 (TVA) & 2.88 & 4.16 & 3.65 & 5.28 & 0.191 & * & ** & NS \\
\hline $\mathrm{C} 18: 1 \mathrm{n} 9 \mathrm{c}$ & 24.1 & 25.6 & 18.2 & 20.0 & 0.868 & 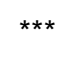 & * & NS \\
\hline C18:1 cis-11 & 0.77 & 0.92 & 0.45 & 0.60 & 0.068 & $* *$ & * & NS \\
\hline C18:2 n6t & 0.35 & 0.39 & 0.30 & 0.30 & 0.028 & NS & NS & NS \\
\hline $\mathrm{C} 18: 2 \mathrm{n} 6 \mathrm{c}$ & 1.66 & 2.80 & 1.37 & 1.59 & 0.180 & NS & * & * \\
\hline cis-9, trans-11 CLA & 1.67 & 2.30 & 2.24 & 2.83 & 0.169 & $\star *$ & ** & * \\
\hline C18:3 n-3 (ALA) & 1.75 & 3.27 & 0.83 & 1.64 & 0.042 & ** & *** & * \\
\hline $\mathrm{C} 20: 0$ & 0.37 & 0.35 & 0.53 & 0.26 & 0.017 & * & * & * \\
\hline$C 20: 4$ & 0.19 & 0.16 & 0.17 & 0.18 & 0.011 & NS & NS & NS \\
\hline C20:5 n-3 (EPA) & 0.32 & 0.36 & 0.21 & 0.28 & 0.024 & * & NS & NS \\
\hline $\mathrm{C} 22: 6 \mathrm{n}-3(\mathrm{DHA})$ & 0.30 & 0.45 & 0.22 & 0.37 & 0.029 & $\dagger$ & * & NS \\
\hline Total n-3 FA & 2.37 & 4.08 & 1.26 & 2.29 & 0.151 & ** & $\star \star \star *$ & * \\
\hline$n-6 / n-3$ & 1.63 & 1.38 & 2.55 & 2.14 & 0.037 & * & $\dagger$ & NS \\
\hline Saturated FA & 64.5 & 57.9 & 70.4 & 64.8 & 0.861 & $\star \star$ & 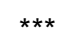 & $\dagger$ \\
\hline Unsaturated FA & 35.6 & 42.1 & 29.6 & 35.2 & 0.552 & 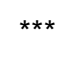 & $\star \star \star ~$ & * \\
\hline Monounsaturated FA & 29.3 & 33.4 & 24.2 & 28.0 & 0.674 & $\star \star$ & $\star \star$ & * \\
\hline Polyunsaturated FA & 6.24 & 8.73 & 5.35 & 7.19 & 0.317 & * & *** & NS \\
\hline$H F A^{3}$ & 34.1 & 29.3 & 39.5 & 35.9 & 0.591 & * & * & $\dagger$ \\
\hline $\mathrm{Al}^{4}$ & 1.74 & 1.28 & 2.17 & 1.66 & 0.107 & * & * & NS \\
\hline \multicolumn{9}{|l|}{$\Delta^{9}-$ desaturase ratios: } \\
\hline $18: 1 / 18: 0+18: 1$ & 0.71 & 0.68 & 0.67 & 0.63 & 0.043 & * & * & NS \\
\hline $\mathrm{RA} / T V A+\mathrm{RA}$ & 0.37 & 0.35 & 0.38 & 0.35 & 0.025 & NS & * & NS \\
\hline TEAC ( $\mu \mathrm{mol}$ TE/g protein) & 0.105 & 0.192 & 0.133 & 0.197 & 0.031 & * & *** & ** \\
\hline
\end{tabular}

${ }^{1} \mathrm{n}=10$ ewes per group; FAME: fatty acid methyl esters; SEM: standard error of mean.

2 S: effect of type of silage; Cs: effect of camelina seed; $S \times C$ s: interaction between type of silage and camelina seed. *** $P<0.001 ;$ ** $P<0.01$; * $P<0.05$; †: $P<0.10$; NS: $P>0.10$.

${ }^{3}$ Hypercholesterolaemic fatty acids (C12:0 + C14:0 + C16:0).

${ }^{4}$ Atherogenicity index $(\mathrm{Al}=(\mathrm{C} 12: 0+(\mathrm{C} 14: 0 \times 4)+\mathrm{C} 16: 0) /$ Unsaturated FA $)$.

FA: fatty acid; TVA: trans-vaccenic acid; CLA: conjugated linoleic acid; ALA: acid a-linolenic; EPA: eicosapentaenoic acid; DHA: docosahexaenoic acid; TEAC: trolox equivalent antioxidant capacity. 
phytosterols) of camelina seed (Budin et al., 1995; Zubr \& Matthaus, 2002), which provide a better oxidative stability of PUFA in camelina oil than fish oil and other vegetable oils rich in PUFA (Ni Eidhin et al., 2011). An increase in the total antioxidant status was noted in the milk of cows whose diets were supplemented with fish oil and linseed (Puppel et al., 2012).

\section{Conclusions}

This study showed that the maize silage diets may result in higher concentrations of cis-9, trans-11 CLA and trans-11 C18:1 and a lower C18:3 n-3 in milk fat. Camelina seeds are important sources of PUFA, especially a-linolenic acid, which positively affects the milk FA profile. Milk fat from ewes fed grass silage seemed to have a nutritionally more propitious composition than fat from ewes fed maize silage. Supplementing ewe diets with camelina seed could improve the nutritional quality of milk fats, owing to higher concentrations of $\alpha$-linolenic acid and nutritionally beneficial trans-FAs (such as CLA and TVA) and the lower content of HFA. The best FA profile in milk in terms of human health effects was obtained from sheep fed a grass-silage-based diet and supplemented with camelina seed. Supplementation with camelina seed has proved useful in providing the most complete human food from an antioxidant perspective. Thus, the nutritional quality and safety of the food can be increased through reducing the oxidizing decay of fat in the milk, which can lead to the formation of toxic secondary compounds and the development of smells and aromas unspecific to milk.

\section{Acknowledgements}

This work was supported by CNCSIS-UEFISCDI, project number PN II - IDEI 679/2008.

\section{References}

AbuGhazaleh, A.A., Felton, D.O. \& Ibrahim, S.A., 2007. Milk conjugated linoleic acid response to fish oil and sunflower oil supplementation to dairy cows managed under two feeding systems. J. Dairy Sci. 90, 4763-4769.

Andrade, P.V.D. \& Schmidely, Ph., 2006. Influence of percentage of concentrate in combination with rolled canola seeds on performance, rumen fermentation and milk fatty acid composition in dairy goats. Livest. Sci. 104, 77-90.

AOAC, 1996. Official methods of analysis (16th ed.). Association of Official Analytical Chemists, Inc. Arlington, Virginia, USA.

Bernard, L., Rouel, J., Leroux, C., Ferlay, A., Faulconnier, Y., Legrand, P. \& Chilliard, Y., 2005. Mamary lipid metabilism and milk fatty acid secretion in Alpine goats fed vegetable lipids. J. Dairy Sci. 88, 1478-1489.

Budin, J.T., Breene, W.M. \& Putnam, D.H., 1995. Some compositional properties of camelina (Camelina sativa L. Crantz) seeds and oils. J. Am. Oil Chem. Soc. 72, 309-315.

Chauveau-Duriot, B., Thomas, D., Portelli, J. \& Doreau, M., 2005. Carotenoids content in forages: variation during conservation. Renc. Rech. Ruminants 12, 117-125.

Chilliard, Y. \& Ferlay A., 2004. Dietary lipids and forage interactions on cow and goat milk fatty acid composition and sensory properties. Reprod. Nutr. Devel. 44, 467-492.

Chilliard, Y., Ferlay, A., Doreau, M., 2001. Effect of different types of forages, animal fat or marine oils in cow's diet on milk fat secretion and composition, especially conjugated linoleic acid and polyunsaturated fatty acid. Livest. Prod. Sci. 70, 31-48.

Chilliard, Y., Ferlay, A., Rouel, J. \& Lambere, G., 2003. A review of nutritional and physiological factors affecting goat milk synthesis and lipolysis. J. Dairy Sci. 86, 1751-1770.

Chouinard, P.Y., Corneau, L., Barbano, D.M., Metzger, L.E. \& Bauman, D.E. 1999. Conjugated linoleic acids alter milk fatty acid composition and inhibit milk fat secretion in dairy cows. J. Nutr. 129, 1579-1584.

Christie, W.W., 1982. A simple procedure of rapid transmethylation of glycerolipids and cholesterol esters. J. Lipid Res. 23, 1072-1075.

Cieslak, A., Kowalczyk, J., Czauderna, M., Potkanski, A. \& Szumacher-Strabel, M., 2010. Enhancing unsaturated fatty acids in ewe's milk by feeding rapeseed or linseed oil. Czech J. Anim. Sci. 55 (11), 496-504.

Claeys, W.L., Verraes, C., Cardoen, S., De Block, J., Huyghebaert, A., Raes, K., Dewettinck, K. \& Herman, L., 2014. Consumption of raw or heated milk from different species: An evaluation of the nutritional and potential health benefits. Food Control 42, 188-201.

Dubois, M., Gilles, K., Hamilton, K., Rebers, A. \& Smith, F., 1956. Colorimetric method for determination of sugars and related substances. Anal. Chem. 28, 350-356.

Ferlay, A., Glasser, F., Martin, B., Andueza, D. \& Chilliard, Y., 2011. Effects of feeding factors and breed on cow milk fatty acid composition: Recent data. Bulletin UASVM, Vet. Med. 68 (1), 137-145. 
FIL (Fédération Internationale Laitie're), 1991. Laits secs, mélanges secs pour cre'mes glacées et fromages fondus. Détermination de la teneur en lactose (Méthodes enzymatiques). 79B. IDF-FIL, Brussels, Belgium. (in French).

Givens, D.I. \& Rulquin, H., 2004. Utilisation by ruminants of nitrogen compounds in silage-based diets. Anim. Feed Sci. Technol. 114, 1-18.

Gomez-Cortes, P., Frutos, P., Mantecon, A.R, Juarez, M., De La Fuente, M.A. \& Hervas, G., 2008. Addition of olive oil to dairy ewe diets: Effect on milk fatty acid profile and animal performance. J. Dairy Sci. 91, 3119-3127.

Gomez-Cortes, P., Frutos, P., Mantecon, A.R., Juarez, M., de la Fuente, M.A. \& Harvas, G., 2009. Effect of supplementation of grazing dairy ewes with a cereal concentrate on animal performance and milk fatty acid profile. J. Dairy Sci. 92, 3964-3972.

Gómez-Cortés, P., Toral, P.G., Frutos, P., Juárez, M., de la Fuente, M. \& Hervás, G., 2011. Effect of the supplementation of dairy sheep diet with incremental amounts of sunflower oil on animal performance and milk fatty acid profile. Food Chem. 125, 644-651.

Havemose, M.S., Weisbjerg, M.R., Bredie, W.L.P., Poulsen, H.D. \& Nielsen, J.H., 2006. Oxidative stability of milk influenced by fatty acids, antioxidants, and copper derived from feed. J. Dairy Sci. 89, 1970-1980.

Hunter, J. \& Roth, G., 2010. Camelina production and potential in Pennsylvania. http://www.agsci.psu.edu

Hurtaud, C. \& Peyraud, J.L., 2007. Effects of feeding Camelina (seeds or meal) on milk fatty acid composition and butter spreadability. J. Dairy Sci. 90, 5134-5145.

INRA, 1989. Ruminant Nutrition. Recommended Allowances and Feed Tables. Eds: Jarrige, R., Libbrey, J. \& INRA, London \& Paris. pp. 193-212.

ISO, 1999a. Animal feeding stuffs determination of moisture and other volatile matter content. International Organization for Standardization, Geneva, Switzerland.

Kalac, P. \& Samkova, E., 2010. The effects of feeding various forages on fatty acid composition of bovine milk fat: A review. Czech J. Anim. Sci. 55 (12), 521-537.

Kliem, K.E., Morgan, R., Humphries, D.J., Shingfield, K.J. \& Givens, D.I., 2008. Effect of replacing grass silage with maize silage in the diet on bovine milk fatty acid composition. Animal 2, 1850-1858.

Lynch, A., Kerry, J.P., Buckley, D.J., Morrissey, P.A. \& Lopez-Bote, C., 2001. Use of high pressure liquid chromatography (HPLC) for the determination of CDA-tocopherol levels in forage (silage/grass) samples collected from different regions in Ireland. Food Chem. 72, 521-524.

Lock, A.L. \& Shingfield, K.J., 2004. Optimising milk composition. In: Dairying - using science to meet consumers' needs. British Society of Animal Science, publication no. 29. Eds: Kebreab, E., Mills, J. \& Beever, D.E., Nottingham University Press, Nottingham, UK. pp. 107-188.

Lopez-Huertas, E., 2010. Health effects of oleic acid and long chain omega-3 fatty acids (EPA and DHA) enriched milks. A review of intervention studies. Pharmacol. Res. 61, 200-207.

Massaro, M., Carluccio, M.A. \& de Caterina, R., 1999. Direct vascular antiatherogenic effects of oleic acid: a clue to the cardioprotective effects of the Mediterranean diet. Cardiologia 44, 507-513.

Mele, M., Buccioni, A., Petacchi, F., Serra, A., Banni, S., Antongivanni, M. \& Secchiari, P., 2006. Effect of forage/concentrate ratio and soybean oil supplementation on milk yield, and composition from Sarda ewes. Anim. Res. 55, 273-285.

Mierlita, D., Daraban, St., Lup, F. \& Chereji, A., 2011. The effect of grazing management and camelina seed supplementation in the diet on milk performance and milk fatty acid composition of dairy ewes. J. Food Agric. Environ. 9 (3\&4), 368-373.

Ni Eidhin, D. \& O' Beirne, D., 2011. Oxidative stability and acceptability of camelina oil blended with selected fish oils. Eur. J. Lipid. Sci. Technol. 112, 878-886.

Nielsen, T.S., Straarup, E.M., Vestergaard, M. \& Sejrsen, K., 2006. Effect of silage type and concentrate level on conjugated linoleic acids, trans-C18:1 isomers and fat content in milk from dairy cows. Reprod. Nutr. Dev. 46, 699-712.

Nudda, A., Battacone, G., Usai, M.G., Fancelli, S. \& Pulina, G., 2006. Supplementation with extruded linseed cake affects concentrations of conjugated linoleic acid and vaccenic acid in goat milk. J. Dairy Sci. 89, 277-282.

Park, Y.W., Juarez, M., Ramos, M. \& Haenlein, G.F.W., 2007. Physico-chemical characteristics of goat and sheep milk. Small Rumin. Res. 68, 88-113.

Puppel, K., Nałecz-Tarwacka, T., Kuczyńska, B., Gołebiewski, M., Kordysz, M. \& Grodzki, H., 2012. The age of cows as a factor shaping the antioxidant level during a nutritional experiment with oil and linseed supplementation for increasing the antioxidant value of milk. J. Sci. Food Agric. 92, 2494-2499.

Puppel, K., Nałecz-Tarwacka, T., Kuczyńska, B., Marcin, G. \& Grodzki, H., 2013. Increasing nutritional value of cow's milk through diet manipulation: Fish oil versus combined supplementation of fish oil and linseed. J. Anim. Prod. Adv. 3 (1), 20-27. 
Renobales, M., Amores, G., Arranz, J., Virto, M., Barrón, L.J.R., Bustamante, M.A., Ruiz de Gordoa, J.C., Nájera, A.I., Valdivielso, I., Abilleira, E., Beltrán de Heredia, I., Pérez- Elortondo, F.J., Ruiz, R., Albisu, M. \& Mandaluniz, N., 2012. Part-time grazing improves sheep milk production and its nutritional characteristics. Food Chem. 130, 90-96.

Samkova, E., Pešek, M., Špička, J., Pelikanova, T. \& Hanuš, O., 2009. The effect of feeding diets markedly differing in the proportion of grass and maize silages on bovine milk fat composition. Czech J. Anim. Sci. 54 (3), 93-100.

SAS, 2001. Statistical Analysis System for Microsoft Windows. Release 8.2. SAS Institute Inc., Cary, N.C., USA.

Shingfield, K.J., Reynolds, C.K., Lupoli, B., Toivonen, V., Yurawecz, M.P., Delmonte, P., Griinari, J.M., Grandison, A.S. \& Beever, D.E., 2005. Effect of forage type and proportion of concentrate in the diet on milk fatty acid composition in cows given sunflower oil and fish oil. Anim. Sci. 80, 225-238.

Slots, T., Butler, G., Leifert, C., Kristensen, T., Skibsted, L.H. \& Nielsen, J.H., 2009. Potentials to differentiate milk composition by different feeding strategies. J. Dairy Sci. 92, 2057-2066.

Sukhija, P.S. \& Palmquist, D.L., 1988. Rapid method for determination of total fatty acid content and composition of feedstuffs and faeces. J. Agric. Food Chem. 36, 1202-1206.

Toral, P.G., Frutos, P., Hervás, G., Gómez-Cortés, P., Juárez, M. \& de la Fuente, M.A., 2010. Changes in milk fatty acid profile and animal performance in response to fish oil supplementation, alone or in combination with sunflower oil, in dairy ewes. J. Dairy Sci. 93, 1604-1615.

Turpeinen, A.M., Mutanen, M., Aro, A., Salminen, I., Basu, S. \& Palmquist, D.L., 2002. Bioconversion of vaccenic acid to conjugated linoleic acid in humans. Am. J. Clin. Nutr. 76, 504-510.

Van Soest, P.J., Robertson, J.B. \& Lewis, B.A., 1991. Methods for dietary fiber, neutral detergent fiber, and non starch polysaccharides in relation to animal nutrition. J. Dairy Sci. 74, 3583-3597.

Vlaeminck, B., Fievez, V., Cabrita, A.R.J., Fonseca, A.J.M. \& Dewhurst, R.J., 2006. Factors affecting oddand branched-chain fatty acids in milk. Anim. Feed Sci. Technol. 131, 389-417.

Williams, C.M., 2000. Dietary fatty acids and human health. Ann. Zootech. 49, 165-180.

Zubr, J. \& Matthaus, B., 2002. Effects of growth conditions on fatty acids and tocopherols in Camelina sativa oil. Ind. Crops Prod. 15, 155-162. 